\title{
Cytotoxic activity of withanolides isolated from Tunisian Datura metel $\mathrm{L}$.
}

Amor Bellila $^{\mathrm{a}}$, Cindy Tremblay ${ }^{\mathrm{b}}$, André Pichette ${ }^{\mathrm{b}}$, Brahim Marzouk ${ }^{\mathrm{a}}$, Vakhtang Mshvildadze $^{\mathrm{b}}$, Serge Lavoie ${ }^{\mathrm{b}}$ and Jean Legault $\mathrm{t}^{\mathrm{b}, *}$

aAromatic and Medicinal Plants Unit, Biotechnological Center in Borj-Cedria Techno-park, 901, Hammam-Lif, Tunisia.

${ }^{\mathbf{b}}$ Chaire de recherche sur les agents anticancéreux d'origine naturelle, Département des sciences fondamentales, Université du Québec à Chicoutimi, Québec, Canada, G7H 2B1.

Correspondence: Jean Legault, jean_legault@uqac.ca, Phone 001-418-545-5011. Fax. 001418- 545-5012. 


\begin{abstract}
Withanolide-type steroids, withametelin Q (1) and 12 $\alpha$-hydroxydaturametelin B (2) along with three known withanolides, were isolated from leaves of Datura metel L (Solanaceae). The respective structures, characterized mainly by NMR spectroscopy, were identified as (20R,22R,24R)-21,24-epoxy-1 $\alpha, 3 \beta$-dihydroxywitha-5,25(27)-dienolide-3-O- $\beta$-D glucopyranoside (1) and (20R,22R,24R)-12 $\alpha, 21,27$-trihydroxy-1-oxowitha-2,5,24-trienolide27-O- $\beta$-D-glucopyranoside (2). The cytotoxicity of isolated compounds was evaluated against human lung carcinoma cells (A549) and human colorectal adenocarcinoma cells (DLD-1), respectively. Compound 2 exhibited cytotoxicity against A549 and DLD-1 cell lines, with $\mathrm{IC}_{50}$ values of 7 and $2.0 \mu \mathrm{M}$, respectively. However, for compounds 6 and 7, cytotoxicities were higher against DLD-1 cells with $\mathrm{IC}_{50}$ of 0.6 and $0.7 \mu \mathrm{M}$. Both compounds blocked the cell cycle in S-phase and induce apoptosis.
\end{abstract}

Keywords: Datura metel L., Solanaceae, Cytotoxic activity, Steroids, withametelin Q, $12 \alpha-$ hydroxydaturametelin B. 


\section{Introduction}

Datura metel L. is a medicinal herb of the Solanaceae family. It has been used in traditional medicine, as a fumigant in bronchial asthma, and for its relaxing effect on the smooth musculature of the bronchi and bronchioles (Smith et al., 1991; Pretorius and Marx, 2006). Datura leaves have been used in India and Africa as a treatment for respiratory disorders which has been demonstrated to relieve asthma (Lewis and Elvin-Lewis, 1977). In Tunisia, Datura aerial parts are used in folk medicine for their antiasthmatic, antispasmodic and antiparkinsonian properties (Le Floc'h, 1983). The chemical investigations of Datura species demonstrated that leaves and seeds especially were rich in alkaloids, including atropine, hyoscyamine, and scopolamine (Berkov et al., 2006; Miraldi et al., 2001). These compounds are included in many official pharmacopoeias because of their anticholinergic activities.

Recently, several pharmacological investigations have been conducted on Datura. In fact, different extracts obtained from this genus have been reported to exhibit antimicrobial (Kagale et al., 2004 ; Eftekhar et al., 2005; Uzun et al., 2004) and antifungal activities (Dabur et al., 2004; Rajesh and Sharma, 2002) as well as hypoglycemic (Krishna Murthy et al., 2004) and antimutagenic properties (Reid et al., 2006).

Cytotoxic activity studies of Datural metel L. have established the presence of several withanolide-type steroids which inhibit cell growth of human cancer cell lines (Ma et al., 2006 ; Pan et al., 2007). In the present study, the bioguided fractionation of the $\mathrm{MeOH}$ extract from the leaves of Datura metel L. and the isolation and structure elucidation of two new withanolide-type steroids are reported.

\section{Results and discussion}

D. metel leaves were extracted using $\mathrm{MeOH}$ and $\mathrm{MeOH}-\mathrm{H}_{2} \mathrm{O}(80: 20)$ with a yield of $18 \%$. The cytotoxicity of $\mathrm{MeOH}-\mathrm{H}_{2} \mathrm{O}$ extract was assessed against human lung carcinoma (A549), colorectal adenocarcinoma (DLD-1) and normal skin fibroblast (WS1) cell lines. The results were obtained using resazurin assay and are expressed as the concentration inhibiting fifty percent of cell growth $\left(\mathrm{IC}_{50}\right)$ (data not shown). The $\mathrm{MeOH}-\mathrm{H}_{2} \mathrm{O}$ extract was cytotoxic against A549, DLD-1 and WS1 cells with $\mathrm{IC}_{50}$ values of $11.9,3.1$ and $7.9 \mu \mathrm{g} \mathrm{mL}{ }^{-1}$, respectively. A bioguided fractionation of the $\mathrm{MeOH}-\mathrm{H}_{2} \mathrm{O}$ extract was conducted in order to isolate and identify the compounds responsible of the activity. The $\mathrm{MeOH}-\mathrm{H}_{2} \mathrm{O}$ extract was successively partitioned with $n$-hexane, dichloromethane and EtOAc. The cytotoxicity of each fraction was 
again tested. The results showed that the three partitions were cytotoxic against cancer and normal cell lines with $\mathrm{IC}_{50}$ values ranging from 1.8 to $11.9 \mu \mathrm{g} \mathrm{mL}^{-1}$ (data not shown).

The EtOAc partition ( $\mathrm{IC}_{50} 3.9$ to $9.5 \mu \mathrm{g} / \mathrm{mL}$ ) was selected for further separation because the extraction yield was higher (13.2 g) in comparison with $n$-hexane (1.4 g) and dichloromethane partitions $(1.1 \mathrm{~g})$. The EtOAc partition was then fractionated on Diaion HP-20 resulting in five new fractions named A, B, C, D and E and all were tested for their biological activities. The results showed that fraction $\mathrm{B}$ exerted highest cytotoxicity against $\mathrm{A} 549\left(\mathrm{IC}_{50}=5.3 \mu \mathrm{g} \mathrm{mL} \mathrm{m}^{-1}\right)$ and DLD-1 $\left(\mathrm{IC}_{50}=2 \mu \mathrm{g} \mathrm{mL}^{-1}\right)$ cells, compared to fractions A, C, D and E. Fraction B $(3.5 \mathrm{~g})$ was separated by repeated column chromatography to afford 9 fractions (B1-B9). Fractions $\mathrm{B} 1$ to $\mathrm{B} 6$ showed highest cytotoxicity with $\mathrm{IC}_{50}$ values ranging from 0.5 to $5.5 \mu \mathrm{g} \mathrm{mL}^{-1}$ (data not shown). These bioactive fractions were submitted to fractionation by combining column chromatography and preparative reversed-phase HPLC to give five pure compounds. Three known compounds daturametelin B (6), withametelin (7) and daturametelin A (8), were identified by NMR spectroscopic analysis and comparison with literature data (Shingu et al., 1987). Unknown compounds 1 and 2 were identified using NMR and mass spectroscopy as described below.

Compound 1 was obtained as a white amorphous solid with a molecular formula of $\mathrm{C}_{34} \mathrm{H}_{50} \mathrm{O}_{10}$ as determined from its HRMS pseudomolecular ion peak at $m / z 641.3295$ (calcd. 641.3302 for $\left.[\mathrm{M}+\mathrm{Na}]^{+}\right)$. IR absorption bands were observed at 3383, 2938, 1725, 1223 and $1066 \mathrm{~cm}^{-1}$ suggesting the presence of an alcohol and an $\alpha, \beta$-unsaturated lactone. The ${ }^{13} \mathrm{C}$ and DEPT-135 NMR spectra of 1 showed peaks attributed to six quaternary, fourteen methine, eleven methylene, and three methyl carbons. Detailed analysis of ${ }^{1} \mathrm{H}$ and HSQC spectra confirmed the presence of a trisubstituted double bond at $\delta_{\mathrm{C}} 139.1(\mathrm{C}-5), 125.4(\mathrm{C}-6)$ and $\delta_{\mathrm{H}} 5.52(1 \mathrm{H}$, m, H-6), a terminal olefin at $\delta_{\mathrm{H}} 6.09$ and 6.67 (each $1 \mathrm{H}, \mathrm{s}, \mathrm{H}_{2}-27$ ) and three tertiary methyl groups at $\delta_{\mathrm{H}} 0.73\left(3 \mathrm{H}, \mathrm{s}, \mathrm{H}_{3}-18\right), 1.02\left(3 \mathrm{H}, \mathrm{s}, \mathrm{H}_{3}-19\right)$ and $1.43\left(3 \mathrm{H}, \mathrm{s}, \mathrm{H}_{3}-28\right)$, almost identical to those of withametelin (7) (Shingu et al., 1987; Oshima et al., 1987). The difference between compound 1 and 7 was established by ${ }^{1} \mathrm{H}-{ }^{1} \mathrm{H}$ COSY coupling of two oxymethine protons at $\delta_{\mathrm{H}} 3.81(1 \mathrm{H}$, br s, H-1) and $4.05(1 \mathrm{H}, \mathrm{tt}, J=4.8$ and $11.1 \mathrm{~Hz})$ with a methylene group at $\delta_{\mathrm{H}} 1.83\left(1 \mathrm{H}, \mathrm{m}, \mathrm{H}-2_{\mathrm{ax}}\right)$ and $2.13\left(1 \mathrm{H}, \mathrm{m}, \mathrm{H}-2_{\mathrm{eq}}\right)$ suggesting the presence of a 1,3dihydroxy group. The latter was located in ring A from the long-range correlations between H3-19 and $\delta_{\mathrm{C}} 73.6$ (C-1), 42.6 (C-9), 42.8 (C-10) and 139.1 (C-5). The sugar moiety, characterized by COSY, was determined to be $\beta$-glucose as supported by the large coupling 
constant of the anomeric proton at $\delta_{\mathrm{H}} 4.37\left(1 \mathrm{H}, \mathrm{d}, J=7.8 \mathrm{~Hz}, \mathrm{H}-1^{\prime}\right)$ (Agrawal, 1992). Furthermore, long-range correlations between $\mathrm{H}-1^{\prime}$ and $\mathrm{C}-3$ and between $\mathrm{H}-3$ and $\mathrm{C}-1^{\prime}$ indicated that the $\beta$-glucosyl unit was attached to C-3.

The ${ }^{1} \mathrm{H}$ and ${ }^{13} \mathrm{C}$ NMR chemical shifts of ring $\mathrm{C}$ and $\mathrm{D}$ and of the lactonic side-chain are almost identical to withametelin (7) (Oshima et al., 1987), also isolated in this work. This comparison in important since the absolute stereochemistry of compound 7 was indirectly determined by a X-ray crystallographic analysis (Shingu et al., 1990). Thus, the relative configuration of the side-chain, which was difficult to establish from NOESY data, could be deduced to be the same than compound 7. Furthermore, unambiguous NOESY correlations between $\mathrm{H}_{3}-18$ and $\mathrm{H}-20$ and $\mathrm{H}-21$ confirmed the $\beta$-configuration of C-17. Stereochemistry in rings $A$ and $B$ were linked to rings $\mathrm{C}$ and $\mathrm{D}$ through NOESY correlation of $\mathrm{H}_{3}-19$ and $\mathrm{H}_{3}-18$ with H-8. The configurations of the alcohol groups were determined to be $1 \alpha$ and $3 \beta$ from the multiplicity of their associated proton signal (broad singlet for $\mathrm{H}-1$ and triplet of triplet for H3) which was further confirmed from NOESY correlation between $\mathrm{H}_{3}-19$ and $\mathrm{H}-1$ and between $\mathrm{H}-3$ and $\mathrm{H}-2 \alpha$ and $\mathrm{H}-4 \alpha$.

Acid hydrolysis of compound $\mathbf{1}$ allowed isolation of (+)-D-glucose (as measured by optical polarimetry from the aqueous fraction) and the rearranged aglycone $\mathbf{5}$ from organic phase. NMR spectra of compound $\mathbf{5}$ showed the presence of an aromatic ring which was located in ring A from the HMBC correlations between $\delta_{\mathrm{H}} 2.18\left(3 \mathrm{H}, \mathrm{s}, \mathrm{H}_{3}-19\right)$ and $\delta_{\mathrm{C}} 137.1(\mathrm{C}-4), 135.9$ (C-5) and $128.2(\mathrm{C}-3)$ and between $\delta_{\mathrm{H}} 7.12(1 \mathrm{H}, \mathrm{d}, \mathrm{s}=7.6 \mathrm{~Hz}, \mathrm{H}-1)$ and $\delta_{\mathrm{C}} 45.8(\mathrm{C}-9)$. This result could be explained by acid-catalyzed dehydratation of $\mathbf{1}$ followed by rearrangement of

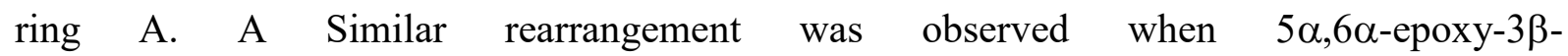
methanesulfonoxyandrostan-17-one was treated with $\mathrm{HBr}$ in acetic acid (Hanson, 1983). To the best of our knowledge, aromatic compound $\mathbf{5}$ has never been described elsewhere. The native aglycone 3 was finally obtained after enzymatic hydrolysis at $37^{\circ} \mathrm{C}$. From the above data, the structure of 1 was identified as $(20 R, 22 R, 24 R)-21,24$-epoxy-1 $\alpha, 3 \beta$-dihydroxywitha5,25(27)-dienolide-3-O- $\beta$-D glucopyranoside.

Compound 2 was isolated as a white amorphous solid with a molecular formula of $\mathrm{C}_{34} \mathrm{H}_{48} \mathrm{O}_{11}$ as determined from its HRESIMS pseudomolecular ion at $\mathrm{m} / z$ 655.3091 (calcd. 655.3094 for $\left.[\mathrm{M}+\mathrm{Na}]^{+}\right)$. Strong bands were observed in IR spectrum at 3369, 2915, 1682, 1663, $1076 \mathrm{~cm}^{-1}$ suggesting the presence of alcohols and $\alpha, \beta$-unsaturated ketones. The ${ }^{1} \mathrm{H}$ and ${ }^{13} \mathrm{C} \mathrm{NMR}$ 
spectra were found to be almost identical to those of daturametelin B (6), also isolated during this work. Careful analysis of COSY, HSQC and HMBC spectra allow determination of an additional alcohol function at $\mathrm{C}-12$. This was supported by $\mathrm{HMBC}$ correlation between $\mathrm{H}_{3}-18$ and $\mathrm{C}-12$ at $\delta_{\mathrm{C}} 74.6$. The stereochemistry at position 12 was determined to be $\alpha$ since $\mathrm{H}-12$ at $\delta_{\mathrm{H}} 4.05$ is a broad singlet. Acid hydrolysis of compound 2 afforded (+)-D-glucose (as measured by optical polarimetry from the aqueous fraction) and the aglycone 4, which has never been described in the literature. Furthermore, long-range correlation between H-1' and C-26 and between $\mathrm{H}_{2}-27$ and $\mathrm{C}-1$ ' indicated that the $\beta$-glucosyl unit was attached to C-27. Therefore, the structure of $\mathbf{2}$ was elucidated as $(20 R, 22 R, 24 R)-12 \alpha, 21,27$-trihydroxy-1oxowitha-2,5,24-trienolide-27-O- $\beta$-D-glucopyranoside.

The cytotoxicity of compounds 1, 2, 6-8 was evaluated against A549, DLD-1 and WS1 cell lines and the results are displayed in Table 4. Etoposide and camptothecin were used as positive controls with $\mathrm{IC}_{50}$ values respectively of 7 and $0.11 \mu \mathrm{M}$ for $\mathrm{A} 549$ and 4 and $0.31 \mu \mathrm{M}$ for DLD-1. The results showed that the isolated withanolides were significantly more active against DLD-1 than A549 cells. However, no significant selectivity for cancer cells was observed in comparison with normal cells. Compounds $\mathbf{6}$ and 7 were found to be strongly cytotoxic against DLD-1 cells $\left(\mathrm{IC}_{50}=0.6-0.7 \mu \mathrm{M}\right)$ and their activities were significantly higher than etoposide and compounds 1, 2, 8 and slightly lower than the camptothecin. The results showed that new withanolides $\mathbf{1}$ and known compound $\mathbf{8}$ were moderately active against DLD-1 with $\mathrm{IC}_{50}$ values of $17 \mu \mathrm{M}$ and $24 \mu \mathrm{M}$, respectively. Interestingly, new compound 2 was also found to be strongly active against DLD-1 ( $\left.\mathrm{IC}_{50}: 2 \mu \mathrm{M}\right)$ with a cytotoxicity higher than etoposide $\left(\mathrm{IC}_{50}: 4 \mu \mathrm{M}\right)$. Unfortunately, cytotoxicities of the aglycone of glycosides 1, 2, 6 and $\mathbf{8}$ were not assessed because isolated quantities were not sufficient. The presence of an hydroxyl group on the carbon 21 of compound 6 increases significantly (about 40 fold) the cytotoxicity against DLD-1 cells in comparison with compound 8 . However, the presence of another hydroxyl group on the carbon 12 of compound 2 reduced significantly (about 3 fold) the cytotoxicity in comparison with compound 6.

As compounds 6 and 7 were strongly cytotoxic against DLD-1 cells, experiments were conducted to evaluate their mode of action. Several studies have shown that withanolides extracted from Whitania somnifera induce accumulation of cells in sub-G1 (Senthil et al., 2007) or in G0/G1 after treatment of a new withanolide, tubocapsenolide A, in MDA-MB-231 cells (Chen et al., 2008). Therefore, the effect of compounds 6 and 7 was evaluated on the cell 
cycle distribution using flow cytometry. Camptothecin used as positive control induces a cell cycle arrest in S-phase and early G2 (Del Bino et al., 1992). The results are presented in Fig. 2A. After 24 hours, the viability of cells treated with both withanolides was greater than $85 \%$ (data not shown). Surprisingly, the results show after 24 hours that, as camptothecin, both withanolides induce an accumulation of DLD-1 cells in the S-phase (43\% to $77 \%$ of cells) in comparison with $33 \%$ for untreated cells. To our knowledge, this is the first report of an induction of cell cycle arrest in the S-phase by withanolides. A possible explanation is that withenolides possess a lactone ring which could inhibit topoisomerase I activity as camptothecin (Ulukan and Swaan, 2002). However, this assumption will be verified. On the other hand, some withanolides have been shown to induce apoptosis by activating caspases (Senthil et al., 2007) or potentiate apoptosis by inhibiting NF-кB activation (Ichikawa et al., 2006). Moreover, S-phase blockage induced by camptothecin results in apoptosis (Del Bino et al., 1992). Therefore, the effect of compounds 6 and 7 on the induction of apoptosis in DLD-1 cells was assessed using flow cytometry. After 48 hours, over $90 \%$ of cells treated with compounds 6 and 7 were not viable. The results presented in Fig. 2B show that both compounds induce preferentially apoptotis at a low dose of $0.1 \mu \mathrm{M}$ with $93 \%$ (compound 6 ) and $67 \%$ (compound 7) of cells in sub-G1. In contrast, at a high dose of $5 \mu \mathrm{M}$, compounds 6 and 7 induce necrosis with a percentage of cells larger than $80 \%$. Altogether, these results showed that withanolides 6 and 7 induce DLD-1 cell blockage in the S-phase and promoted programmed cell death at low dose and necrosis at high dose.

\section{Concluding remarks}

In conclusion, eight withanolides were isolated from leaves of Datura metel L including two new structures (1 and 2). Two compounds (6 and 7) were found strongly active against colorectal cancer cell line, DLD-1. In contrast to others withanolides previously reported in the literature, compounds $\mathbf{6}$ and $\mathbf{7}$ blocked the cell in S-phase as camptothecin, a topoisomerase I inhibitor.

\section{Experimental}

\subsection{General experimental procedures}

Reversed phase-high performance liquid chromatography analyses were carried out using an analytical Agilent 1100 series with diode array detection and equipped with an Inertsil ODS$\mathrm{C}_{18}$ column $(4.6 \mathrm{~mm} \times 250 \mathrm{~mm}, 5 \mu \mathrm{m})$ at room temperature, with $\mathrm{MeOH}-\mathrm{H}_{2} \mathrm{O}(85: 15)$ used as 
mobile phase. The preparative HPLC instrument used in this study was a preparative Agilent 1100 HPLC Series. Separation was carried out on this system with an Inerstil Prep ODS column $(20 \mathrm{~mm} \times 250 \mathrm{~mm}, 10 \mu \mathrm{m}) . \mathrm{MeOH}-\mathrm{H}_{2} \mathrm{O}(85: 15)$ was used as a mobile phase with flow rate $2 \mathrm{~mL} \mathrm{~min}^{-1}$. Analytical thin-layer chromatography (TLC) was performed with silica gel $60 \mathrm{~F}_{254}, 0.25 \mathrm{~mm}$ pre-coated TLC plates (Silicycle, Québec, Canada) using $\mathrm{CHCl}_{3} / \mathrm{MeOH} / \mathrm{H}_{2} \mathrm{O}$ as the mobile phase. Compounds were visualized under visible light after spraying the plates with $20 \% \mathrm{H}_{2} \mathrm{SO}_{4}$ solution in EtOH followed by $1 \%$ vanillin in EtOH and heated at $110^{\circ} \mathrm{C}$ for $5 \mathrm{~min}$. The $230-400$ mesh silica gel (Silicycle, Québec, Canada) was used for column chromatography (CC). Nuclear magnetic resonance (NMR) spectra were recorded on a Bruker Avance spectrometer at $400 \mathrm{MHz}\left({ }^{1} \mathrm{H}\right)$ and $100 \mathrm{MHz}\left({ }^{13} \mathrm{C}\right)$, equipped with a $5 \mathrm{~mm}$ QNP probe. Elucidations of chemical structures were based on ${ }^{1} \mathrm{H},{ }^{13} \mathrm{C}, \mathrm{COSY}$, TOCSY, HMBC, HSQC and DEPT-135 experiments. Signals are reported as m (multiplet), s (singlet), d (doublet), $\mathrm{t}$ (triplet), dd (doublet of doublet), dt (doublet of triplet), ddd (doublet of doublet of doublet), br s (broad singlet) and coupling constants are reported in hertz (Hz). The chemical shifts are reported in ppm $(\delta)$ relative to tetramethylsilane (TMS). The exchangeable $\mathrm{OH}$ NMR signals appearing sometimes were not listed. Optical rotations were obtained using the sodium D line at ambient temperature on a Rudolph Research Analytical Autopol IV automatic polarimeter. Accurate mass measurements (HRMS) were performed on a LC-MSDTOF instrument from Agilent Technologies in positive electrospray mode. FTIR spectra were obtained using $\mathrm{KBr}$ disks on a Perkin-Elmer Spectrum One Instrument. Chemical reagents were purchased from Sigma-Aldrich Co. Canada or Alfa Aesar Co. and were used as received. The solvents were obtained from VWR International Co. and were used as received.

\subsection{Plant material}

Datura metel L. was collected in August 2008 from its natural habitat in south Tunisia. Leaves were air-dried in darkness at ambient temperature and ground to a fine powder with an electrical mortar. Botanical identification of this species was carried out by Prof. A. Smaoui (Biotechnologic Center in Borj-Cedria Technopark, Tunisia), according to the Tunisian flora (Pottier-Alapetite, 1979). A voucher specimen was deposited in the Aromatic and Medicinal Plants Unit, Biotechnological Center in Borj-Cedria Techno-park, Hammam-Lif, Tunisia (D.m.08003). 


\subsection{Extraction and isolation}

Dried and powdered leaves $(0.5 \mathrm{~kg})$ of the plant were extracted with $\mathrm{MeOH}(3 \times 3 \mathrm{~L})$ followed by $\mathrm{MeOH}-\mathrm{H}_{2} \mathrm{O}(80: 20)(2 \times 2 \mathrm{~L})$, under reflux for $8 \mathrm{~h}$. A sample of $10 \mathrm{~mL}$ of the solution of $\mathrm{MeOH}-\mathrm{H}_{2} \mathrm{O}$ extract was evaporated to dryness to assess the extraction yield to $18 \%(\mathrm{w}, \mathrm{w})$. The organic phase of the $\mathrm{MeOH}-\mathrm{H}_{2} \mathrm{O}$ solution was evaporated. The aqueous residue was treated with $n$-hexane $(3 \times 500 \mathrm{~mL})$ and with $\mathrm{CH}_{2} \mathrm{Cl}_{2}(3 \times 500 \mathrm{~mL})$ to remove chlorophyll and other lipophilic constituents. The steroids were finally extracted from the aqueous residue with EtOAc $(7 \times 500 \mathrm{~mL})$. The EtOAc phase was concentrated to produce a brown powder (13.2 g).

\subsection{Bioguided fractionation}

The EtOAc fraction was subjected to Diaion HP-20 (Supelco, USA) CC eluting with $\mathrm{H}_{2} \mathrm{O}$ EtOH under increasing percentages of $\mathrm{EtOH}$ (from $30 \%$ to $100 \%, \mathrm{v}, \mathrm{v}$ ) to give five fractions: A $(0.82 \mathrm{~g}), \mathrm{B}(3.51 \mathrm{~g})$; C $(2.90 \mathrm{~g})$; D $(0.26 \mathrm{~g})$; E (0.25 g). Cytotoxicity of all fractions was tested against two cancer cell lines and one normal cell line. The most active fraction B was subjected to open on silica gel CC, eluted with a solvent mixture in various proportions of $\mathrm{CHCl}_{3}-\mathrm{MeOH}-\mathrm{H}_{2} \mathrm{O}$ (55:6:0.5); (50:7:0.5); (50:10:0.5) (50:12:0.5); (50:15:0.5) and finally eluted with $\mathrm{MeOH}$, affording 9 fractions (B1-B9). The B1-B6 fractions showed greatest in vitro cytotoxicity against both cancer cell lines. These fractions were further applied to a series of silica gel $\mathrm{CC}$ eluting with $\mathrm{CHCl}_{3}-\mathrm{MeOH}-\mathrm{H}_{2} \mathrm{O}(50: 10: 0.5)$ and with $\mathrm{CHCl}_{3}-\mathrm{MeOH}$ $(80: 1),(50: 1),(25: 1)$. Finally, isolation was completed by preparative reversed-phase HPLC. New compounds 1 (26.2 mg) and 2 (35.3 mg) were isolated from B4. Daturametelin B (6) $(100.6 \mathrm{mg})$ was isolated from B1 and B2 and daturametelin D (7) (50.9 mg) was isolated from B3. Daturametelin A (8) (16.8 mg) was isolated from B5. All known compounds were identified by comparing spectroscopic data with reported values.

\subsubsection{Daturamalakoside A (20R,22R,24R)-21,24-epoxy-1 $\alpha, 3 \beta$-dihydroxywitha 5,25(27)-} dienolide-3-O- $\beta$-D-glucopyranoside (1)

White amorphous solid. $[\alpha]_{\mathrm{D}}^{25}-35.96^{\circ}(\mathrm{c}=1, \mathrm{MeOH})$. IR $v_{\max }: 3383,2938,2906,2868$, 1725, 1382, 1223, 1066, $1016 \mathrm{~cm}^{-1}$; HRESIMS $\mathrm{m} / z$ : 641.3295. Calcd for $\mathrm{C}_{34} \mathrm{H}_{50} \mathrm{O}_{10} \mathrm{Na}$ : 641.3302. For ${ }^{1} \mathrm{H}$ and ${ }^{13} \mathrm{C}$ NMR spectroscopic data (see Table 2 and 3 ). 


\subsubsection{Daturamalakoside $B \quad(20 R, 22 R, 24 R)-12 \alpha, 21,27-t r i h y d r o x y-1$-oxowitha-2,5,24-}

trienolide-27-O- $\beta$-D-glucopyranoside (2)

Light yellow amorphous solid. $[\alpha]_{\mathrm{D}}^{25}+11.90^{\circ}\left(\mathrm{c}=1\right.$, MeOH). IR $v_{\max }$ : 3369, 2915, 1682, 1663, 1398, 1076, $1038 \mathrm{~cm}^{-1}$; HRESIMS m/z: 655.3092. Calcd for $\mathrm{C}_{34} \mathrm{H}_{48} \mathrm{O}_{11} \mathrm{Na}: 655.3094$. For ${ }^{1} \mathrm{H}$ and ${ }^{13} \mathrm{C}$ NMR spectroscopic data (see Table 2 and 3 ).

4.4.3. Daturamalakin A (20R,22R,24R)-21,24-epoxy-1 $\alpha, 3 \beta$-dihydroxywitha-5,25(27)dienolide (3)

White amorphous solid. $[\alpha]_{\mathrm{D}}^{25}-39.9\left(\mathrm{c}=0.4, \mathrm{CHCl}_{3}\right)$. IR $v_{\max }: 3400,2917,1718,1565$, 1223, $756 \mathrm{~cm}^{-1}$; HRESIMS $\mathrm{m} / z$ : 457.2952. Calcd for $\mathrm{C}_{28} \mathrm{H}_{40} \mathrm{O}_{5}: 457.2954$. For ${ }^{1} \mathrm{H}$ and ${ }^{13} \mathrm{C}$ NMR spectroscopic data (see Table 2 and 3).

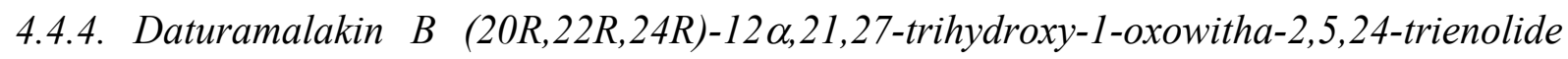
(4)

Light yellow amorphous solid. $[\alpha]_{\mathrm{D}}{ }^{25}+18.1\left(\mathrm{c}=0.4, \mathrm{CHCl}_{3}\right)$. IR $v_{\max }$ : 3386, 2922, 1663, 1381, 1078, $754 \mathrm{~cm}^{-1}$; HRESIMS m/z: 493.2564. Calcd for $\mathrm{C}_{28} \mathrm{H}_{38} \mathrm{O}_{6} \mathrm{Na}$ : 493.2566. For ${ }^{1} \mathrm{H}$ and ${ }^{13} \mathrm{C}$ NMR spectroscopic data (see Table 2 and 3 ).

\subsubsection{Phenowithanolide (5)}

White amorphous solid. $[\alpha]_{\mathrm{D}}{ }^{25}-3.61^{\circ}\left(\mathrm{c}=0.5, \mathrm{CHCl}_{3}\right)$. IR $v_{\max }$ : 2938, 2868, 1720, 1381, 1220, 753, $666 \mathrm{~cm}^{-1}$; HRESIMS m/z: 420.2731. Calcd for $\mathrm{C}_{28} \mathrm{H}_{36} \mathrm{O}_{3}: 420.2737$. For ${ }^{1} \mathrm{H}$ and ${ }^{13} \mathrm{C}$ NMR spectroscopic data (see Table 2 and 3 ).

\subsection{Acid hydrolysis}

In screwed cap vials, $10 \%$ of $\mathrm{HCl}(10 \mathrm{~mL})$ was individually added to compound $\mathbf{1}$ and $\mathbf{2}$ (10 mg each). The resulting solutions heated at $100{ }^{\circ} \mathrm{C}$ for $4 \mathrm{~h}$. The aglycones were extracted with $\mathrm{CHCl}_{3}(3 \times 10 \mathrm{~mL})$, and the aqueous phases containing sugars were neutralized with $10 \% N$-methyl- $N, N$-di-n-octylamine. Monosaccharides were analyzed by TLC with authentic samples using $\mathrm{CH}_{2} \mathrm{Cl}_{2}-\mathrm{MeOH}-\mathrm{H}_{2} \mathrm{O}$ (50:25:5), spots were visualized using naphthoresorcinol solution in $\mathrm{EtOH}$. 


\subsection{Enzymatic hydrolysis}

Compounds 1 and $2(20 \mathrm{mg})$ were dissolved in $50 \mathrm{~mL}$ acetate buffer $(10 \mathrm{~g}$ sodium acetate anhydrous, $1.6 \mathrm{~mL}$ glacial acetic acid, $500 \mathrm{~mL} \mathrm{H}_{2} \mathrm{O}$ and $\mathrm{pH} \mathrm{5)}$ and $200 \mathrm{mg}$ of $\beta$-glycosidase from almonds (7-8 IU mg ${ }^{-1}$ ) was added. The mixture was incubated at $40{ }^{\circ} \mathrm{C}$ for $22 \mathrm{~h}$. After the hydrolysis, the reaction mixture was extracted with $\mathrm{CHCl}_{3}(3 \times 50 \mathrm{~mL})$ (Moreau and Hicks, 2004). The residue (aglycone), after evaporating and drying, was analyzed by NMR.

\subsection{Cell culture}

The human lung carcinoma A549 (\#CCL-185), colorectal adenocarcinoma DLD-1 (\#CCl221) and skin fibroblast WS1 (\#CRL-1502) cell lines were obtained from the American Type Culture Collection (ATCC, Manassas, USA). Cells lines were grown in minimum essential medium containing Earle's salts (Mediatech Cellgro ${ }^{\circledR}$, Herndon, USA), supplemented with $10 \%$ fetal calf serum (Hyclone, Logan, USA), $1 \times$ solution of vitamins, $1 \times$ sodium pyruvate, $1 \times$ non-essential amino acids, $100 \mathrm{IU}$ of penicillin and $100 \mu \mathrm{g} \mathrm{mL}^{-1}$ of streptomycin (Mediatech Cellgro $\left.{ }^{\circledR}\right)$. Cells were cultured at $37^{\circ} \mathrm{C}$ in a humidified atmosphere containing $5 \% \mathrm{CO}_{2}$.

\subsection{Cytotoxic assay}

Exponentially growing cells were plated at a density of $5 \times 10^{3}$ cells per well in 96-well microplates (BD Falcon) in culture medium $(100 \mu \mathrm{L})$ and were allowed to adhere for $16 \mathrm{~h}$ before treatment. Then, cells were incubated for $48 \mathrm{~h}$ in the presence or absence of $100 \mu \mathrm{L}$ of increasing concentrations of extract, fraction or pure compounds dissolved in culture medium and DMSO. The final concentration of DMSO in the culture medium was maintained at $0.25 \%(\mathrm{v} / \mathrm{v})$ to avoid toxicity. Cytotoxicity was assessed using the resazurin reduction test (O’Brien et al., 2000). Fluorescence was measured on an automated 96-well Fluoroskan Ascent $\mathrm{Fl}^{\mathrm{TM}}$ plate reader (Labsystems) using an excitation wavelength of $530 \mathrm{~nm}$ and an emission wavelength of $590 \mathrm{~nm}$. Cytotoxicity was expressed as the concentration of drug inhibiting cell growth by $50 \%\left(\mathrm{IC}_{50}\right)$.

\subsection{Flow cytometry}

Cell cycle was evaluated by flow cytometry as described by Pollack and Cianco (1990). Briefly, an amount of $0.5 \times 10^{6}$ cells were plated in petri dishes and were allowed to adhere 
for $24 \mathrm{~h}$. After 24 or $48 \mathrm{~h}$ of treatment with selected concentration of products, cell pellet resuspended in $50 \mu \mathrm{L}$ PBS was supplemented with propidium iodide $\left(20 \mu \mathrm{g} \mathrm{mL}^{-1}\right)$. After 15 min of incubation on ice, cells were fixed in $25 \%$ ethanol in PBS. After addition of Hoechst reagent $\left(112 \mu \mathrm{g} \mathrm{mL}^{-1}\right)$, cells were analyzed using an EPICS ELITE ESP (BeckmanCoulter, Québec, Canada) flow cytometer. Cell cycle analysis was performed with the MulticycleAV software (Phoenix flow system, San Diego, CA).

\section{Acknowledgements}

The authors wish to kindly thank C. Dussault for its technical assistance. This study was supported by the Tunisian Ministry for high education, research and technology and by the "Chaire de recherche sur les agents anticancéreux d'origine naturelle" of the Université du Québec à Chicoutimi, Canada.

\section{References}

Agrawal, P.K., 1992. NMR Spectroscopy in the structural elucidation of oligosaccharides and glycosides. Phytochemistry 31, 3307-3330.

Berkov, S., Zayed, R., Doncheva, T., 2006. Alkaloid patterns in some varieties of Datura stramonium. Fitoterapia 77, 179-182.

Chen, W.Y., Chang, F.R., Huang, Z.Y., Chen, J.H., Wu, Y.C., Wu, C.C., 2008. Tubocapsenolide A, a novel withanolide, inhibits proliferation and induces apoptosis in MDA-MB-231 cells by thiol oxidation of heat shock proteins. J. Biol. Chem. 25, 1718417193.

Dabur, R., Singh, H., Chhillar, A.K., Ali, M., Sharma, G.L., 2004. Antifungal potential of Indian medicinal plants. Fitoterapia 75, 389-391.

Del Bino, G., Bruno, S., Yi, P.N., Darzynkiewicz, Z., 1992. Apoptotic cell death triggered by camptothecin or teniposide. The cell cycle specificity and effects of ionizing radiation. Cell Prolif. 25, 537-548.

Eftekhar, F., Yousefzadi, M., Tafakori, V., 2005. Antimicrobial activity of Datura innoxia and Datura stramonium. Fitoterapia 76, 118-120. 
Hanson, J.R., Reese, P.B., 1983. A deuterium NMR study of 4-methyloestratriene formation. Tetrahedron 24, 3405-3408.

Ichikawa, H., Takada, Y., Shishodia, S., Jayaprakasam, B., Nair, M.G., Aggarwal, B.B., 2006. Withanolides potentiate apoptosis, inhibit invasion, and abolish osteoclastogenesis through suppression of nuclear factor- $\kappa \mathrm{B}(\mathrm{NF}-\kappa \mathrm{B})$ activation and NF- $\kappa \mathrm{B}-$ regulated gene expression. Mol. Cancer Ther. 5, 1434-1445.

Kagale, S., Marimuthu, T., Thayumanvan, B., Nandakumar, R., Samiyappan, R., 2004. Antimicrobial activity and induction of systemic resistance in rice by leaf extract of Datura metel against Rhizoctonia solani and Xanthomonas oryzae pv. oryzae. Physiol. Mol. plant pathol. $65,91-100$.

Krishna Murthy, B., Nammi, S., Kota, M.K., Krishna Rao, R.V., Koteswara Rao N., Annapurna, A., 2004. Evaluation of hypoglycemic and antihyperglycemic effects of Datura metel (Linn.) seeds in normal and alloxan-induced diabetic rats. J. Ethnopharmacol. 91, 95-98.

Le Floc'h, E., 1983. Contribution à une étude ethnobotanique de la flore tunisienne. Editions Ministère de l'enseignement supérieur et de la recherche scientifique, Tunisie, pp.402.

Lewis, W.H., Elvin-Lewis, M.P.F., 1977. Medical botany: Plants effecting man's health, John Wiley and Sons, New York, pp. 90-93.

Ma, L., Xie, C.M., Li, J., Lou, F.C., Hu, L.H., 2006. Daturametelins H, I, and J: three new withanolide glycosides from Datura metel L. Chem. Biodiv. 3, 180-186.

Miraldi, E., Masti, A., Ferri, S., Barni Comparini, I., 2001. Distribution of hyoscyamine and scopolamine in Datura stramonium. Fitoterapia 72, 644-648.

Moreau, R.A., Hicks, K.B., 2004. The in vitro rates of hydrolysis of phytosterol conjugates and other plant lipids by mammalian digestive enzymes, compared to saponification. Lipids 39, 769-776.

O'Brien, J., Wilson, I., Orton, T., Pognan, F., 2000. Investigation of the Alamar Blue (resazurin) fluorescent dye for the assessment of mammalian cell cytotoxicity. Eur. J. Biochem. 267, 5421-5426. 
Oshima, Y., Bagchi, A., Hikino, H., Sinha, S. C., Sahai, M., B. Ray, A., 1987. Withametelin, a hexacyclic withanolide of Datura metel. Tetrahedron 28, 2025-2027.

Pan, Y., Wang, X., Hu, X., 2007. Cytotoxic withanolides from the flowers of Datura metel. J. Nat. Prod. 70, 1127-1132.

Pollack, A., Ciancio, G., 1990. Cell cycle phase-specific analysis of cell viability using Hoechst 33342 and propidium iodide after ethanol preservation. Methods Cell Biol. 33, $19-24$

Pottier-Alapetite, G., 1979. Flore de la Tunisie. Angiospermes, Dicotylédones Dialypétales. Vol. I, Imprimerie officielle de la république Tunisienne, Tunis, $254 \mathrm{pp}$.

Pretorius, E., Marx, J., 2006. Datura stramonium in asthma treatment and possible effects on prenatal development. Environ. Toxicol. Pharmacol. 21, 331-337.

Rajesh, G. L. Sharma, 2002. Studies on antimycotic properties of Datura metel. J. Ethnopharmacol. 80, 193-197.

Reid, K.A., Maes, J., Maes, A., Van Staden, J., De Kimpe, N., Mulholland, D.A., Verschaeve, L., 2006. Evaluation of the mutagenic and antimutagenic effects of South African plants. J. Ethnopharmacol. 106, 44-50.

Senthil, V., Ramadevi, S., Venkatakrishnan, V., Giridharan, P., Lakshmi, B. S., Vishwakarma, R. A., Balakrishnan, A., 2007. Withanolide induces apoptosis in HL-60 leukemia cells via mitochondria mediated cytochrome c release and caspase activation. Chem. Biol. Inter. 167, 19-30.

Shingu, K., Kajimoto, T., Furusawa, Y., Nohara, T., 1987. The Structures of Daturametelin A and B. Chem. Pharm. Bull. 35, 4359-4361.

Shingu, K., Furusawa, Y., Marubayashi, N., Ueda, I., Yahara, S., Nohara, T., 1990. The structure of daturametelin D. Chem. Pharm. Bull. 38, 2866-2867.

Smith, E.A., Meloan, C.E., Pickell, J.A., Oehme, F.W., 1991. Scopolamine poisoning from home made 'moon flower wine'. J. Anal. Toxicol. 15, 216-219. 
Ulukan, H., Swaan, P.W., 2002. Camptothecins: a review of their chemotherapeutic potential. Drugs 62, 2039-2057.

Uzun, E., Sariyar, G., Adsersen, A., Karakoc, B., Otük, G., Oktayoglu, E., Pirildar, S., 2004. Traditional medicine in Sakarya province (Turkey) and antimicrobial activities of selected species. J. Ethnopharmacol. 95, 287-296. 

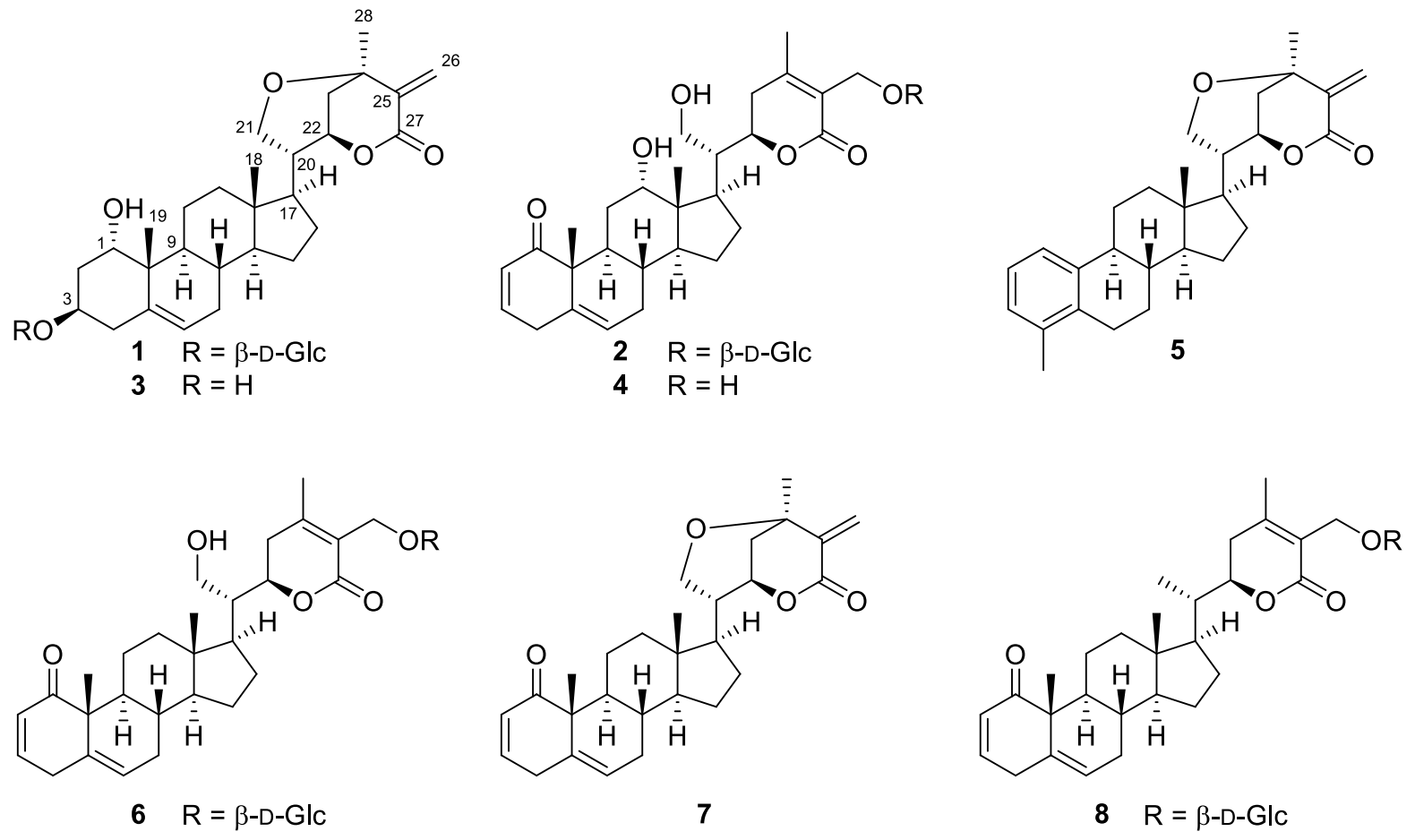

Fig. 1. Structures of compounds 1-8. 
A
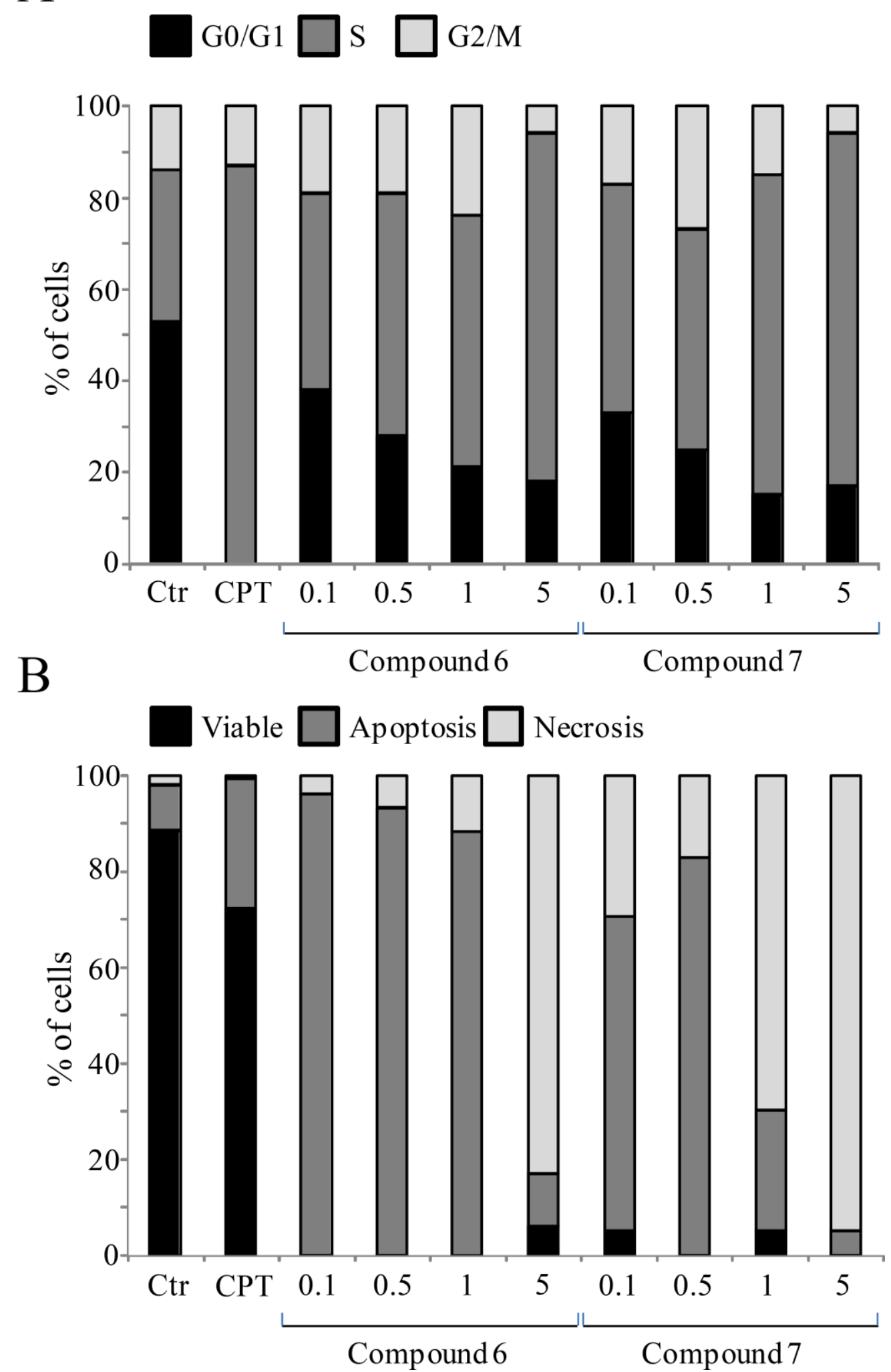

Fig. 2. Withanolide effects on cell cycle after $24 \mathrm{~h}(\mathrm{~A})$ and on the induction of apoptosis or necrosis after $48 \mathrm{~h}$ (B) in DLD-1 cells by flow cytometry analysis. Camptothecin (CPT) $1 \mu \mathrm{M}$ was used as positive control. 
Table $1{ }^{1} \mathrm{H}$ NMR spectroscopic data of compounds $\mathbf{1}-\mathbf{5}$.

\begin{tabular}{|c|c|c|c|c|c|}
\hline Position & $\mathbf{1}^{\mathrm{a}}$ & $2^{\mathbf{a}}$ & $3^{\mathbf{b}}$ & $4^{\mathrm{b}}$ & $\mathbf{5}^{\mathbf{b}}$ \\
\hline 1 & $3.81, b r s$ & & $3.85, b r s$ & & $7.12, d(7.6)$ \\
\hline $2 \mathrm{a}$ & $1.83, m$ & $5.82, d d d(1.0,3.0,9.9)$ & $1.75, m$ & $5.88, d d d(0.8,2.9,9.9)$ & $6.98, t(7.5)$ \\
\hline $2 b$ & $2.13, m$ & & $2.09, m$ & & \\
\hline 3 & $4.05, t t(4.8,11.1)$ & $6.91, d d d(2.4,4.9,9.9)$ & $3.99, t t(4.6,11.5)$ & $6.82, d d d(2.4,4.9,9.9)$ & $6.93, d(6.8)$ \\
\hline $4 a$ & $2.31, m$ & $2.89, d d(4.8,21.3)$ & $2.30, m$ & $2.86, d d(5.1,21.5)$ & \\
\hline $4 b$ & $2.47, m$ & $3.35, m$ & $2.39, m$ & $3.30, m$ & \\
\hline $6 a$ & $5.52, m$ & $5.63, b r d(6.0)$ & $5.60, b r d(5.4)$ & $5.59, b r d(5.7)$ & $2.62, m$ \\
\hline $6 \mathrm{~b}$ & & & & & $2.77, m$ \\
\hline $7 \mathrm{a}$ & $1.61, m$ & $1.63, m$ & $1.62, m$ & $1.64, m$ & $1.38, m$ \\
\hline $7 b$ & $1.97, m$ & $2.02, m$ & $2.01, m$ & $2.00, m$ & $2.00, m$ \\
\hline 8 & $1.50, m$ & $1.48, m$ & $1.51, m$ & $1.46, m$ & $1.36, m$ \\
\hline 9 & $1.74, m$ & $2.00, m$ & $1.65, m$ & $2.03, m$ & $2.27, m$ \\
\hline $11 \mathrm{a}$ & $1.47, m$ & $1.81, m$ & $1.47, m$ & $1.80, m$ & $1.51, m$ \\
\hline $11 \mathrm{~b}$ & $1.57, m$ & $2.46, d t(3.3,14.2)$ & $1.53, m$ & $2.42, d t(3.2,14.5)$ & $2.34, m$ \\
\hline $12 \mathrm{a}$ & $1.42, m$ & $4.05, b r s$ & $1.45, m$ & $4.12, b r s$ & $1.57, m$ \\
\hline $12 b$ & $1.96, m$ & & $1.95, m$ & & $2.09, m$ \\
\hline 14 & $1.19, m$ & $1.72, m$ & $1.17, m$ & $1.77, m$ & $1.35, m$ \\
\hline $15 \mathrm{a}$ & $1.19, m$ & $1.24, m$ & $1.18, m$ & $1.22, m$ & $1.31, m$ \\
\hline $15 \mathrm{~b}$ & $1.72, m$ & $1.75, m$ & $1.71, m$ & $1.72, m$ & $1.82, m$ \\
\hline $16 \mathrm{a}$ & $1.42, m$ & $1.46, m$ & $1.40, m$ & $1.43, m$ & $1.40, m$ \\
\hline $16 \mathrm{~b}$ & $1.83, m$ & $1.79, m$ & $1.75, m$ & $1.72, m$ & $1.85, m$ \\
\hline 17 & $1.81, m$ & $2.15, m$ & $1.77, m$ & $2.18, m$ & $1.87, m$ \\
\hline 18 & $0.73, s$ & $0.82, s$ & $0.69, s$ & $0.76, s$ & $0.75, s$ \\
\hline 19 & $1.02, s$ & $1.25, s$ & $1.03, s$ & $1.22, s$ & $2.18, s$ \\
\hline 20 & $1.81, m$ & $1.83, m$ & $1.86, m$ & $1.85, m$ & $1.85, m$ \\
\hline $21 \mathrm{a}$ & $3.67, d d(1.6,13.2)$ & $3.86, m$ & $3.73, d d(3.0,13.2)$ & $3.85, d d(3.0,12.6)$ & $3.70, d d(1.8,13.3)$ \\
\hline $21 b$ & $3.94, d(13.2)$ & $4.05, d(12.0)$ & 3.91, brd (13.2) & $4.10, m$ & $3.97, d(13.3)$ \\
\hline 22 & $4.70, b r s$ & $4.51, d t(3.4,13.0)$ & $4.66, b r s$ & $4.45, m$ & $4.72, b r s$ \\
\hline $23 \mathrm{a}$ & $1.96, m$ & $2.35, d d(3.2,18.5)$ & $1.90, m$ & $2.19, m$ & $1.97, m$ \\
\hline $23 b$ & $2.13, m$ & $3.06, d d(13.0,18.5)$ & $2.05, m$ & $3.21, d d(16.9,18.6)$ & $2.16, m$ \\
\hline $27 \mathrm{a}$ & $6.09, s$ & $4.47, d(11.3)$ & $6.02, s$ & $4.35, d(12.1)$ & $6.10, s$ \\
\hline $27 b$ & $6.67, s$ & $4.64, d(11.3)$ & $6.76, s$ & $4.42, d(12.1)$ & $6.68, s$ \\
\hline 28 & $1.43, s$ & $2.13, s$ & $1.44, s$ & $2.03, b r s$ & $1.45, s$ \\
\hline $1^{\prime}$ & $4.37, d(7.8)$ & $4.32, d(7.8)$ & & & \\
\hline $2^{\prime}$ & $3.14, d d(7.8,9.1)$ & $3.16, d d(8.0,8.9)$ & & & \\
\hline $3^{\prime}$ & $3.35, m$ & $3.35, m$ & & & \\
\hline $4^{\prime}$ & $3.26, m$ & $3.28, m$ & & & \\
\hline $5^{\prime}$ & $3.26, m$ & $3.27, m$ & & & \\
\hline \multirow[t]{2}{*}{$6^{\prime}$} & $3.85, d d(1.4,11.8)$ & $3.67, d d(5.1,11.6)$ & & & \\
\hline & $3.64, m$ & $3.86, m$ & & & \\
\hline
\end{tabular}

${ }^{\mathrm{a}} \mathrm{Spectra}$ recorded in $\mathrm{CD}_{3} \mathrm{OD}$.

${ }^{\mathrm{b}}$ Spectra recorded in $\mathrm{CDCl}_{3}$. 
Table $2{ }^{13} \mathrm{C}$ NMR spectroscopic data of compounds $\mathbf{1}-\mathbf{5}^{\mathrm{a}}$.

\begin{tabular}{|c|c|c|c|c|c|}
\hline Position & $1^{\mathrm{a}}$ & $2^{a}$ & $\mathbf{3}^{\mathbf{b}}$ & $4^{b}$ & $5^{b}$ \\
\hline 1 & 73.6 & 206.5 & 72.9 & 204.6 & 124.0 \\
\hline 2 & 37.7 & 128.4 & 38.3 & 127.8 & 126.3 \\
\hline 3 & 74.9 & 148.2 & 66.4 & 145.9 & 128.2 \\
\hline 4 & 39.1 & 34.4 & 41.4 & 33.4 & 137.1 \\
\hline 5 & 139.1 & 137.4 & 137.4 & 135.5 & 135.9 \\
\hline 6 & 125.4 & 125.7 & 125.3 & 124.7 & 28.1 \\
\hline 7 & 32.9 & 31.7 & 31.7 & 30.3 & 29.0 \\
\hline 8 & 33.3 & 34.5 & 31.9 & 33.1 & 39.6 \\
\hline 9 & 42.6 & 38.6 & 41.5 & 36.7 & 45.8 \\
\hline 10 & 42.8 & 51.3 & 41.6 & 49.7 & 141.2 \\
\hline 11 & 21.4 & 31.3 & 20.3 & 31.3 & 28.1 \\
\hline 12 & 40.8 & 74.6 & 39.4 & 73.5 & 41.2 \\
\hline 13 & 44.0 & 47.4 & 42.8 & 45.8 & 44.2 \\
\hline 14 & 57.6 & 49.1 & 56.1 & 47.7 & 56.5 \\
\hline 15 & 25.3 & 24.7 & 24.1 & 23.5 & 24.8 \\
\hline 16 & 27.6 & 26.9 & 26.6 & 25.9 & 27.7 \\
\hline 17 & 48.9 & 39.7 & 47.5 & 37.8 & 49.0 \\
\hline 18 & 12.9 & 13.4 & 12.6 & 13.1 & 13.0 \\
\hline 19 & 20.0 & 19.3 & 19.4 & 18.9 & 19.9 \\
\hline 20 & 41.6 & 46.0 & 39.8 & 44.7 & 41.6 \\
\hline 21 & 61.6 & 59.8 & 60.5 & 59.4 & 61.7 \\
\hline 22 & 77.5 & 79.3 & 75.6 & 78.2 & 77.4 \\
\hline 23 & 33.9 & 33.7 & 33.2 & 32.7 & 34.0 \\
\hline 24 & 70.9 & 161.0 & 69.4 & 154.5 & 70.9 \\
\hline 25 & 140.9 & 123.5 & 138.9 & 125.2 & 140.9 \\
\hline 26 & 167.6 & 168.6 & 165.3 & 167.2 & 167.6 \\
\hline 27 & 130.6 & 63.6 & 130.0 & 57.5 & 130.6 \\
\hline 28 & 25.7 & 20.8 & 25.6 & 20.0 & 25.7 \\
\hline $1^{\prime}$ & 102.7 & 104.0 & & & \\
\hline $2^{\prime}$ & 75.2 & 75.1 & & & \\
\hline $3^{\prime}$ & 78.1 & 78.1 & & & \\
\hline $4^{\prime}$ & 71.8 & 71.6 & & & \\
\hline $5^{\prime}$ & 78.0 & 78.1 & & & \\
\hline $6^{\prime}$ & 63.0 & 62.8 & & & \\
\hline
\end{tabular}

${ }^{\text {a }}$ Spectra recorded in $\mathrm{CD}_{3} \mathrm{OD}$.

${ }^{\mathrm{b}}$ Spectra recorded in $\mathrm{CDCl}_{3}$. 